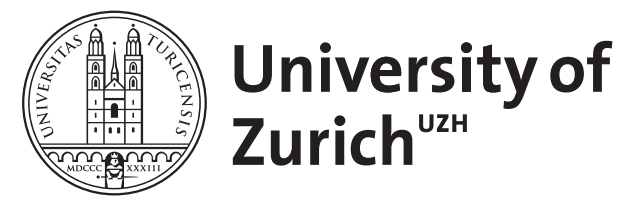

\title{
New and noteworthy Bryophyte records from Croatia
}

Alegro, Antun ; Šegota, Vedran ; Rimac, Anja ; Kiebacher, Thomas ; Prlić, Dragan ; Sedlar, Zorana ; Vuković, Nina ; Papp, Beata

\begin{abstract}
Within the course of a recent, extensive bryophyte survey across the whole country, eight moss taxa have been recorded for the first time in Croatia: Conardia compacta (Drumm. ex Müll. Hal.) H. Rob., Cynodontium tenellum (Schimp.) Limpr., Dichodontium flavescens (Dicks.) Lindb., Fissidens fontanus (Bach. Pyl.) Steud., Orthotrichum philibertii Venturi, Rhabdoweisia crispata (Dicks.) Lindb., Schistidium trichodon (Brid.) Poelt var. trichodon and Tortella fasciculata (Culm.) Culm.. In addition, new localities of five rare taxa are presented: Didymodon tophaceus subsp. sicculus (M.J. Cano, Ros, García-Zam. J. Guerra) Jan Kučera, Ephemerum serratum (Hedw.) Hampe, Mannia triandra (Scop.) Grolle, Oxystegus tenuirostris (Hook. Taylor) A.J.E. Sm. and Sphaerocarpos michelii Bellardi. Ecological and chorological data are provided for each of the reported taxa. Concluding, at the current state of knowledge, Croatian bryoflora includes 705 taxa, out of which 541 mosses, 162 liverworts and two hornworts.
\end{abstract}

DOI: https://doi.org/10.5252/cryptogamie-bryologie2019v40a2

Posted at the Zurich Open Repository and Archive, University of Zurich ZORA URL: https://doi.org/10.5167/uzh-170840

Journal Article

Published Version

Originally published at:

Alegro, Antun; Šegota, Vedran; Rimac, Anja; Kiebacher, Thomas; Prlić, Dragan; Sedlar, Zorana; Vuković, Nina; Papp, Beata (2019). New and noteworthy Bryophyte records from Croatia. Cryptogamie Bryologie, 40(2):3-11.

DOI: https://doi.org/10.5252/cryptogamie-bryologie2019v40a2 


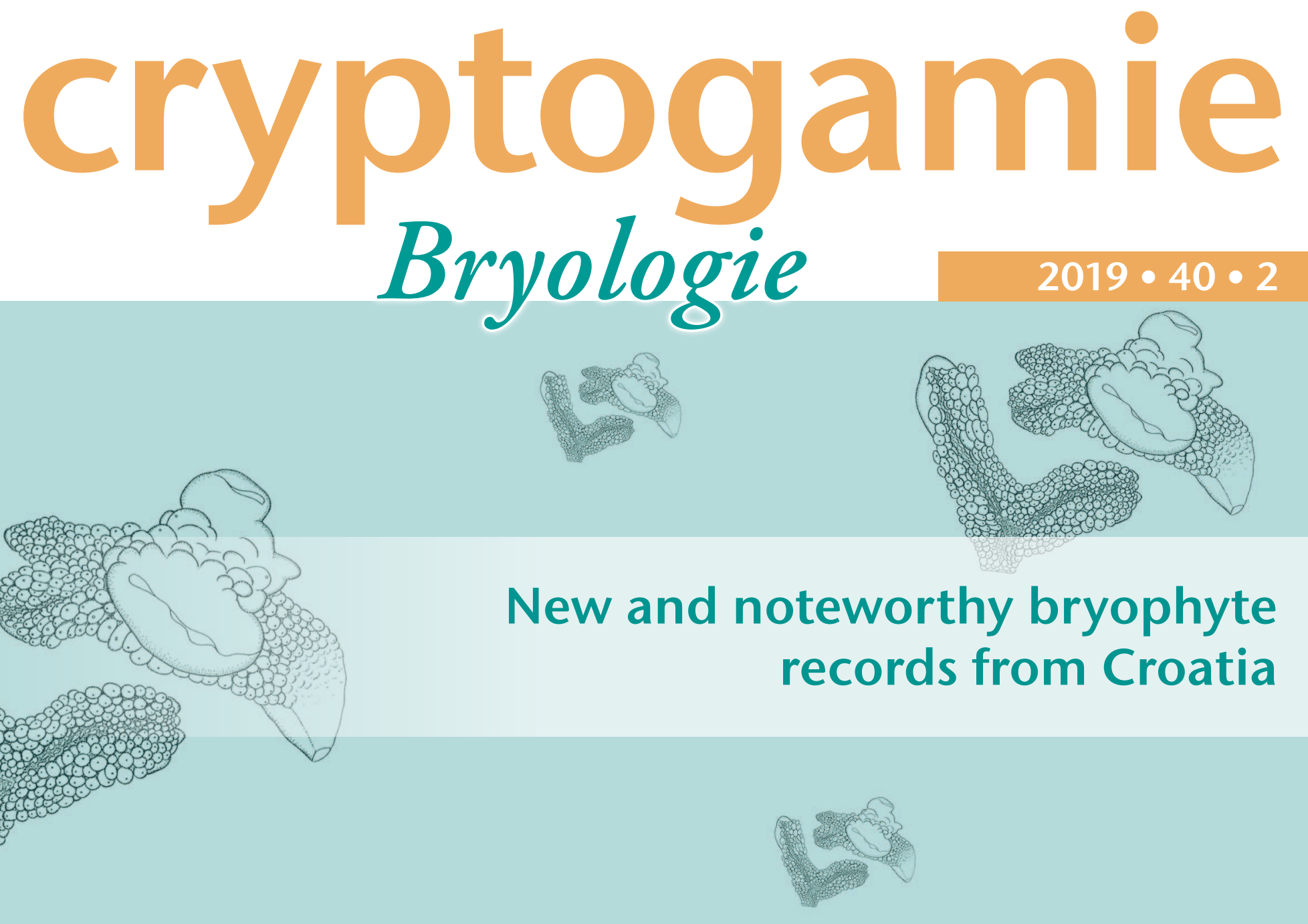

Antun ALEGRO, Vedran ŠEGOTA, Anja RIMAC, Thomas KIEBACHER, Dragan PRLIĆ, Zorana SEDLAR, Nina VUKOVIĆ \& Beata PAPP
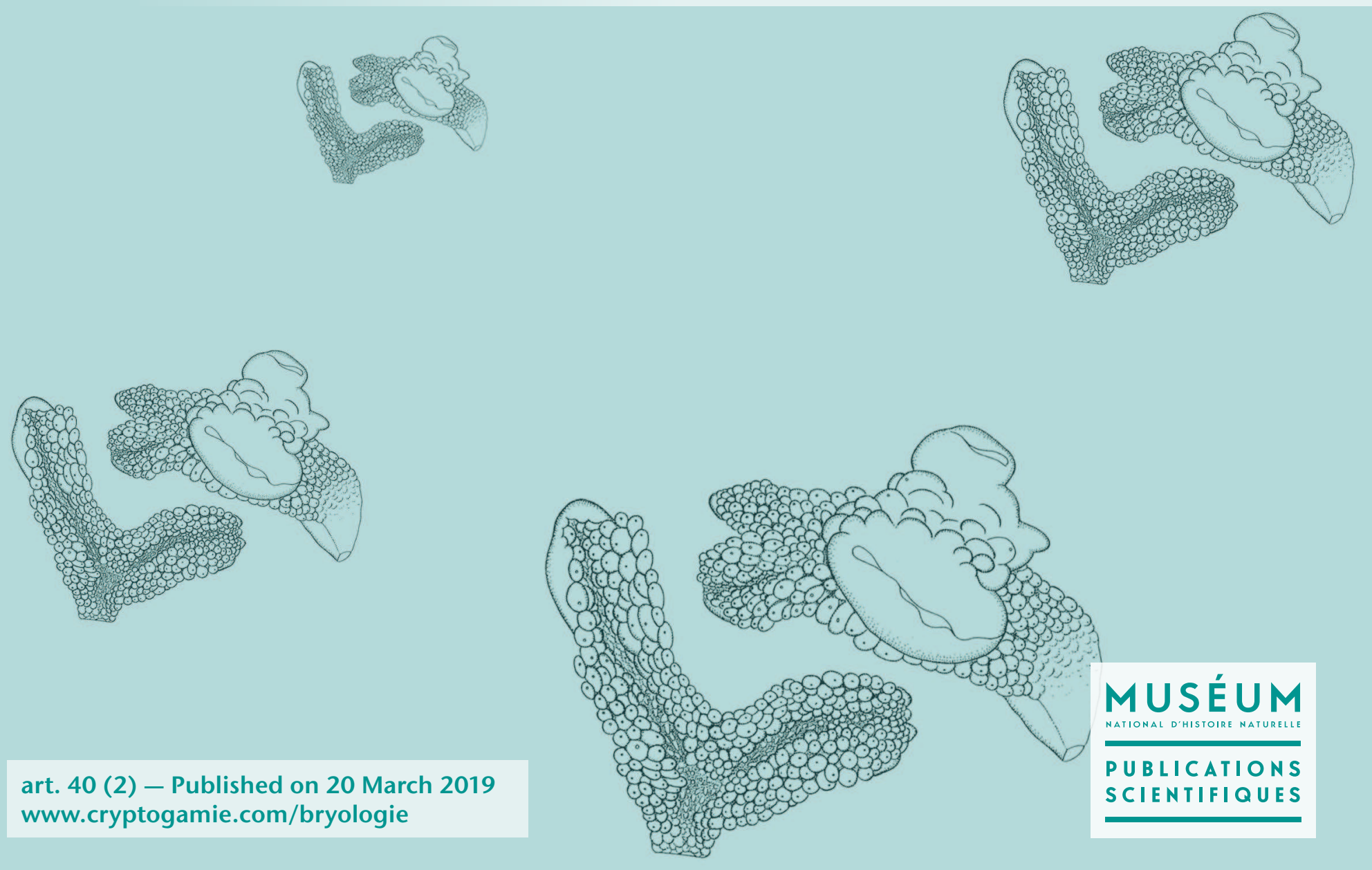
DIRECTEUR DE LA PUBLICATION: Bruno David,

Président du Muséum national d'Histoire naturelle

RÉdACTEURS EN CHEF / EDITORS-IN-CHIEF : Denis LAMY

ASSISTANTS DE RÉDACTION / ASSISTANT EDITORS: Marianne SALAÜN

Mise EN PAGE / PAGE LAYOUT: Marianne SALAÜN

RÉdACTEURS ASSOCIÉS / ASSOCIATE EDITORS

Biologie moléculaire et phylogénie / Molecular biology and phylogeny

Bernard GOFFINET

Department of Ecology and Evolutionary Biology, University of Connecticut (United States)

Mousses d'Europe / European mosses

Rosa Maria ROS ESPIN

Catedrática botánica, Facultad de Biologia, Universidad de Murcia (Spain)

Mousses d'Afrique et d'Antarctique / African and Antarctic mosses

Rysiek OCHYRA

Laboratory of Bryology, Institute of Botany, Polish Academy of Sciences, Krakow (Pologne)

Phylogénie moléculaire, taxonomie et biogéographie des hépatiques / Molecular phylogeny, taxonomy and biogeography of hepaties Jochen HEINRICHS

LMU Department für Biologie, Systematische Botanik und Mykologie, München (Allemagne)

Bryophytes d'Asie / Asian bryophytes

Rui-Liang ZHU

School of Life Science, East China Normal University, Shanghai (China)

Bioindication / Biomonitoring

Franck-Olivier DENAYER

Faculté des Sciences Pharmaceutiques et Biologiques de Lille, Laboratoire de Botanique et de Cryptogamie, Lille (France)

Cryptogamie, Bryologie est indexé dans / Cryptogamie, Bryologie is indexed in:

- Biological Abstracts

- Current Contents

- Science Citation Index

- Publications bibliographiques du CNRS (Pascal).

Cryptogamie, Bryologie est distribué en version électronique par / Cryptogamie, Bryologie is distributed electronically by:

- BioOne ${ }^{\circledR}$ (http://www.bioone.org)

Cryptogamie, Bryologie est une revue en flux continu publiée par les Publications scientifiques du Muséum, Paris Cryptogamie, Bryologie is a fast track journal published by the Museum Science Press, Paris

Les Publications scientifiques du Muséum publient aussi / The Museum Science Press also publish:

Adansonia, Geodiversitas, Zoosystema, Anthropozoologica, European Journal of Taxonomy, Naturae, Cryptogamie sous-sections Algologie, Mycologie.

Diffusion - Publications scientifiques Muséum national d'Histoire naturelle

CP $41-57$ rue Cuvier F-75231 Paris cedex 05 (France)

Tél. : 33 (0)1407948 05 / Fax: 33 (0)140793840

diff.pub@mnhn.fr / http://sciencepress.mnhn.fr

(C) Publications scientifiques du Muséum national d'Histoire naturelle, Paris, 2019

ISSN (imprimé / print): 1290-0796 / ISSN (électronique / electronic): 1776-0992 


\title{
New and noteworthy bryophyte records from Croatia
}

\author{
Antun ALEGRO \\ Vedran ŠEGOTA \\ Anja RIMAC \\ Department of Botany, Faculty of Science,
} University of Zagreb, Marulićev trg 20/II, 10000 Zagreb (Croatia) vedran.segota@biol.pmf.hr

Thomas KIEBACHER Department of Systematic and Evolutionary Botany, University of Zurich UZH, Zollikerstrasse 107, 8008 Zürich (Switzerland)

Dragan PRLIĆ Donji Meljani 92C, 33520 Slatina (Croatia)

Zorana SEDLAR Croatian Natural History Museum, Demetrova 1, 10000 Zagreb (Croatia)

Nina VUKOVIĆ

Department of Botany, Faculty of Science, University of Zagreb, Marulićev trg 20/II, 10000 Zagreb (Croatia)

Beata PAPP

Botanical Department, Hungarian Natural History Museum, PO Box 137, 1431 Budapest (Hungary)

Submitted on 8 March 2018 | Accepted on 27 July 2018 | Published on 20 March 2019

KEY WORDS

Balkans, chorology, liverworts,

Mediterranean mosses,

SE Europe.

Alegro A., Šegota V., Rimac A., Kiebacher T., Prlić D., Sedlar Z., Vuković N. \& Papp B. 2019. - New and noteworthy bryophyte records from Croatia. Cryptogamie, Bryologie 40 (2): 3-11. https://doi.org/10.5252/cryptogamie-bryologie2019v40a2. http://cryptogamie.com/bryologie/40/2

\section{ABSTRACT}

Within the course of a recent, extensive bryophyte survey across the whole country, eight moss taxa have been recorded for the first time in Croatia: Conardia compacta (Drumm. ex Müll. Hal.) H. Rob., Cynodontium tenellum (Schimp.) Limpr., Dichodontium flavescens (Dicks.) Lindb., Fissidens fontanus (Bach. Pyl.) Steud., Orthotrichum philibertii Venturi, Rhabdoweisia crispata (Dicks.) Lindb., Schistidium trichodon (Brid.) Poelt var. trichodon and Tortella fasciculata (Culm.) Culm.. In addition, new localities of five rare taxa are presented: Didymodon tophaceus subsp. sicculus (M.J. Cano, Ros, García-Zam. \& J. Guerra) Jan Kučera, Ephemerum serratum (Hedw.) Hampe, Mannia triandra (Scop.) Grolle, Oxystegus tenuirostris (Hook. \& Taylor) A.J.E. Sm. and Sphaerocarpos michelii Bellardi. Ecological and chorological data are provided for each of the reported taxa. Concluding, at the current state of knowledge, Croatian bryoflora includes 705 taxa, out of which 541 mosses, 162 liverworts and two hornworts. 


\section{RÉSUMÉ \\ Titre en français \\ intro en français}

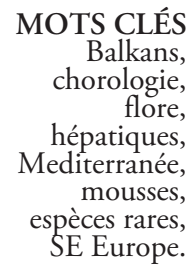

\section{INTRODUCTION}

Bryophytes of the Balkan Peninsula are still poorly known; in fact, the region of SE Europe is bryologically the least investigated area in Europe (Sabovljević 2004; Sabovljević et al. 2011). Croatia is a SE European country situated at the crossroads of Central Europe, the Balkans and the Mediterranean. A historical overview of bryological research in Croatia shows that the peak of research took place during the end of the $19^{\text {th }}$ and the beginning of the $20^{\text {th }}$ century (Alegro et al. 2012), followed by a large gap in research until the last decade. Pavletić (1955), in the mid-20th century, provided the most comprehensive work on the bryophytes of former Yugoslavia by gathering all historical sources and summarizing the distribution of taxa. More recently, Sabovljević $(2003,2006)$ and Ros et al. $(2007,2013)$ provided a checklist for the territory of Croatia, mostly based, however, on historical data. Finally, serious bryological fieldwork in Croatia continued in the $21^{\text {st }}$ century, and dozens of new species were recorded for the country (Papp \& Sabovljević 2009; Ellis et al. 2012a, b, 2014, 2015, 2016, 2017; Papp et al. 2013a, b, c; Alegro et al. 2014, 2015). However, despite considerable progress in the knowledge of the diversity and distribution of Croatian bryophytes in the last decade, a great shortage of data is still evident.

The main objective of this paper is to provide further additions to the inventory of bryophytes in Croatia.

\section{MATERIAL AND METHODS}

The field research was undertaken in the period 2011-2017 across the whole country, with a special emphasis on legally protected areas (national and nature parks) of Croatia. Collected specimens were deposited in the bryophyte collections at ZA and BP and the private collection of T. Kiebacher. The nomenclature follows Ros et al. (2007, 2013), except for Didymodon tophaceus subsp. sicculus (M.J. Cano, Ros, García-Zam. \& J. Guerra) Jan Kučera and Tortella fasciculata (Culm.) Culm, which are according to Kučera et al.
(2018) and Köckinger \& Hedenäs (2017), respectively. The nomenclature of vascular plants is according to Euro+Med (2018). Geoelements are assigned mostly according to Hill \& Preston (1998) and Smith (2004) and for several taxa to Düll (1984, 1992, 1999) and Dierßen (2001). Distributional data are based on Smith (2004), Frey et al. (2006) and Hodgetts (2015). Conservation status in SE Europe follows Sabovljević et al. (2004), Natcheva et al. (2006) and Stefănuț \& Goia (2012) using abbreviations CR for critically endangered, EN for endangered and VU for vulnerable species (IUCN 2017). The revision of the genus Ephemerum Hampe was based on Holyoak (2010) and Ellis \& Price (2015), while this of Tortella fasciculata (Culm.) Culm. on Köckinger \& Hedenäs (2017). The delimitation of the Mediterranean area has been done according to Conservation International Biodiversity Hotspots (2018).

\section{RESULTS AND DISCUSSION}

The study of the samples collected allowed identifying eight new national records and five noteworthy records in Croatia, increasing the richness of Croatian bryophyte flora to 705 taxa, namely 541 mosses, 162 liverworts and two hornworts taxa.

The distribution of the newly recorded bryophytes in Croatia is shown in Figure 1.

\section{NEW NATIONAL RECORDS}

Conardia compacta (Drumm. ex Müll. Hal.) H. Rob.

Specimen examined. - Croatia. Plitvice Lakes National Park,

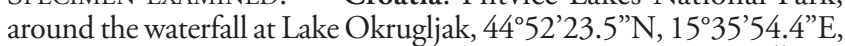
$620 \mathrm{~m}$ a.s.1., 26.IX.2016, leg. and det. B. Papp, A. Alegro \& V. Šegota s.n., BP(BP191472).

The species was found on tufa rocks at the waterfall, not situated in the Mediterranean part of Croatia, accompanied by other bryophytes: Barbula crocea (Brid.) F. Weber \& D. Mohr, Brachythecium rivulare Schimp., Campyliadelphus elodes (Lindb.) Kanda, Conocephalum salebrosum Szweyk., Buczkowska \& Odrzykoski, Cratoneuron filicinum (Hedw.) Spruce, Ctenidium molluscum (Hedw.) Mitt., Fissidens 


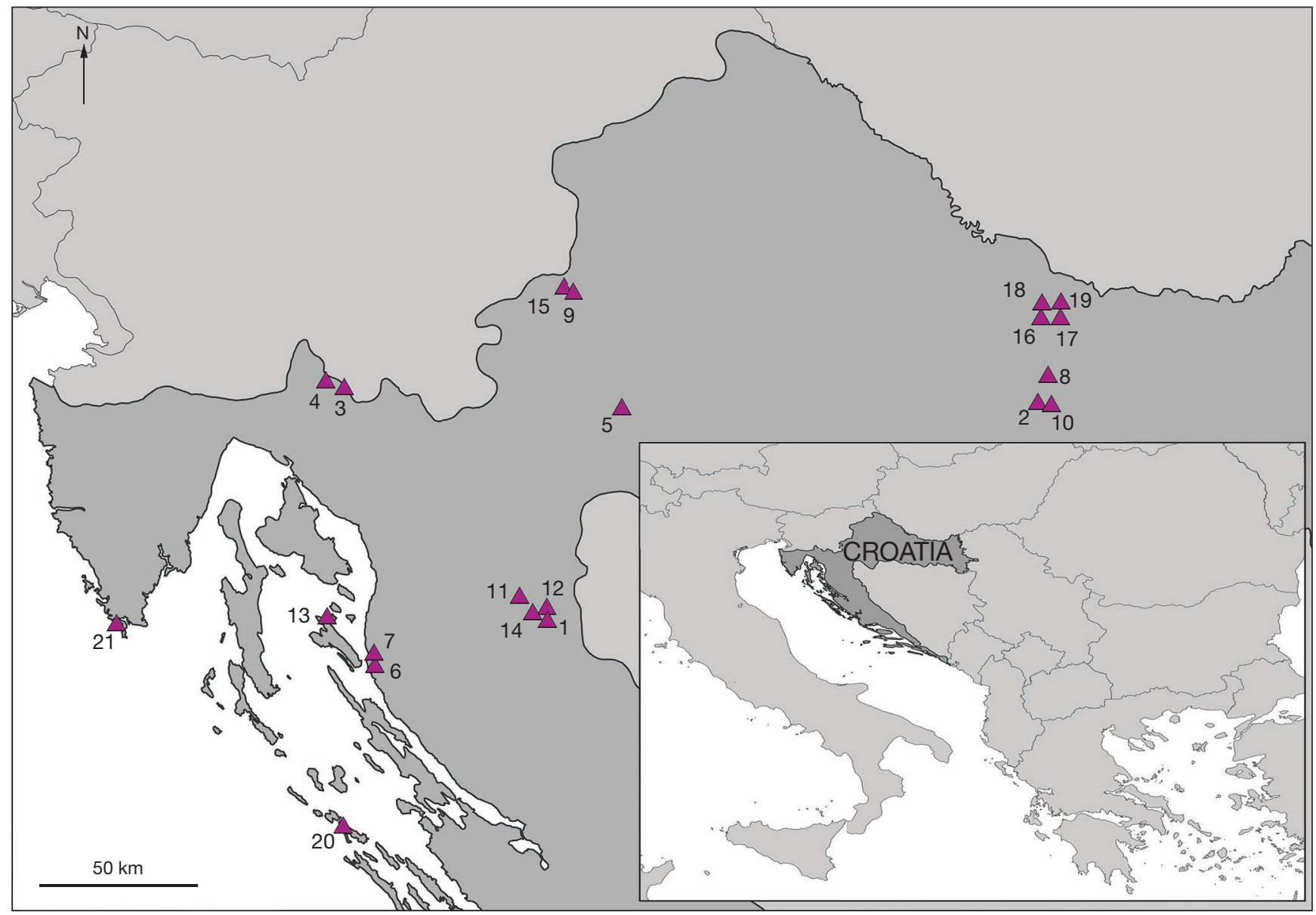

FIG. 1. - Map of Croatia indicating the collection sites of the 13 reported taxa: 1, Conardia compacta; 2 , Cynodontium tenellum; $\mathbf{3}, \mathbf{4}$, Dichodontium flavescens; 5, Fissidens fontanus; 6, 7, Orthotrichum philibertii; 8, Rhabdoweisia crispate; 9, Schistidium trichodon var. trichodon; 10, 11, 12, Tortella fasciculata; 13, Didymodon tophaceus subsp. sicculus; 14, Mannia triandra; 15, Oxystegus tenuirostris; 16, 17, 18, 19, Sphaerocarpos michelii; 20, 21, Ephemerum serratum. Insected map of the right bottom shows position of Croatia in SE Europe.

dubius P. Beauv., Gymnostomum aeruginosum Sm., Hymenostylium recurvirostrum (Hedw.) Dixon, Mnium marginatum (Dicks. ex With.) P. Beauv., Orthothecium rufescens (Dicks. ex Brid.) Schimp., Oxyrrhynchium hians (Hedw.) Loeske, Palustriella commutata (Hedw.) Ochyra and Pellia endiviifolia (Dicks.) Dumort. The population was small, consisting of several tiny patches. However, the plants were well developed. Conardia compacta is a discontinuously Circumpolar Boreal-montane species (Düll 1992; Hill \& Preston 1998; Smith 2004) rather rare in SE Europe, where it is only known from Greece (Gamisans \& Hébrard 1980), Romania (Stefănut \& Goia 2012), Slovenia (Głowacki 1912) and Serbia (Sabovljević et al. 2008). The species is known also from neighbouring Hungary (Papp et al. 2010 b) and Italy (Aleffi et al. 2008). It is considered threatened in several European countries; however, it has not been included in any Red list of SE European countries.

\section{Cynodontium tenellum (Schimp.) Limpr.}

SPECIMEN EXAMINED. - Croatia. Papuk Nature Park, rocks on eastern slopes of Mališćak Peak, 4529'14.1'N, 17³8'15.1”E, 725 m a.s.l., 13.X.2016, leg. and det. A. Alegro \& V. Šegota s.n., conf. B. Papp, BP(BP193751), ZA(ZA45474, ZA45493).

The species was found in a restricted area of several hundred square meters on steep slopes with huge siliceous outcrops and screes within an acidothermophilic Quercus petrea (Matt.) Liebl. forest, where it was confined to rocks, shallow crevices, cracks and fissures. The plants formed dense cushions with numerous sporophytes. This locality is not situated in the Mediterranean part of Croatia. The particular site was very rich in bryophytes, which covered the shaded parts of the rocks and forest floor in carpets (Barbilophozia hatcheri (A. Evans) Loeske, Brachythecium rutabulum (Hedw.) Schimp., Dicranum scoparium Hedw., Hedwigia ciliata (Hedw.) P. Beauv., Hylocomium splendens (Hedw.) Schimp., Hypnum cupressiforme Hedw., Lophozia ventricosa (Dicks.) Dumort., Pleurozium schreberi (Willd. ex Brid.) Mitt., Pohlia nutans (Hedw.) Lindb., Polytrichum formosum Hedw. P. piliferum Hedw., Rhabdoweisia fugax (Hedw.) Bruch \& Schimp.). Cynodontium tenellum is a Circumpolar Boreoarctic Montane species (Hill \& Preston 1998; Smith 2004), present in Central and Northern Europe (Smith 2004). From Balkans it is known from Bosnia and Herzegovina (Głowacki 1906), Bulgaria (Papp \& Erzberger 2007), Romania (Stefănuț \& Goia 2012), Slovenia (Martinčič 2003) and Serbia (Papp \& Erzberger 2005; Erzberger \& Papp 2007). The species is known also from neighbouring Hungary (Erzberger \& Papp 2004) and Italy (Aleffi et al. 2008). It is EN in Romania (Stefănuț \& Goia 2012).

Dichodontium flavescens (Dicks.) Lindb.

SPECIMEN EXAMINED. - Croatia. Gorski Kotar, Kupa River, after the confluence with Čabranka River near the village Gašparci, 
45'30'27'N, 14'46'28”'E, $256 \mathrm{~m}$ a.s.l., 03.VIII.2016, leg. and det. A. Alegro, V. Šegota \& A. Rimac s.n., conf. B. Papp, BP(BP193754), ZA(ZA45475, ZA45476, ZA45477, ZA45478); Gorski Kotar, Čabranka River, at the confluence with Kupa River, 4531'32'N, $14^{\circ} 41$ '58”'E, $291 \mathrm{~m}$ a.s.1., 03.VIII.2016, leg. and det. A. Alegro, $V$. Šegota \& A. Rimac s.n., conf. B. Papp, .

In the Kupa River, the species was growing in small patches, on periodically flooded, slightly inclined and not particularly shaded limestone rocks on riverbanks. The moss was well developed, but without capsules. The accompanied species were Brachythecium rutabulum, Cratoneuron filicinum, Fissidens crassipes Wilson ex Bruch \& Schimp., Hygrohypnum luridum (Hedw.) Jenn., Marchantia polymorpha L. and Palustriella falcata (Brid.) Hedenäs, while in the running water only Cinclidotus riparius (Host ex Brid.) Arn., Fontinalis antipyretica Hedw. and Rhynchostegium riparioides (Hedw.) Cardot were present. In the Cabranka River the species was scarce, also growing on periodically flooded limestone rocks on the riverbank, but in comparison to the previous locality the habitat was shaded by trees (Alnus glutinosa (L.) Gaertn. and Salix alba L.). The specimens were without capsules. Other species found were Brachythecium mildeanum (Schimp.) Schimp., B. rivulare, Cratoneuron filicinum and Fissidens crassipes. In the watercourse, bryophyte flora consisted of Cinclidotus aquaticus (Hedw.) Bruch \& Schimp., Fontinalis antipyretica and Rhynchostegium riparioides. Both localities are not situated in the Mediterranean part of Croatia. All examined specimens had acute, sharply and irregularly toothed leaf apex, weak teeth on dorsal surface of nerve and weak papillae on lamina cells, all of which are characteristic for D. flavescens (Werner 2002). On the other hand, ratio of leaf length and width was 4.0-4.2, which is close to values for D. pellucidum (Werner 2002). Although many authors have recognized it at species level (see Werner 2002), others have treated it as a variety of $D$. pellucidum (Frey et al. 2006), or placed it in the synonymy with the latter (Brugués \& Ruiz 2015), due to the uncertain delimitation of these taxa. D. flavescens is a Suboceanic Montane species (Düll 1984), present in Western, Central and Northern Europe (Hodgetts 2015). In SE Europe it is known only from Montenegro (Papp \& Erzberger 2011) and Romania (Stefănuț \& Goia 2012), in latter being VU (Stefãnuț \& Goia 2012). From neighbouring countries it is known from Italy (Aleffi et al. 2008).

\section{Fissidens fontanus (Bach. Pyl.) Steud.}

Specimen eXamined. - Croatia. Banovina Region, Trepča River, $45^{\circ} 27^{\prime} 41^{\prime \prime} \mathrm{N}, 15^{\circ} 54^{\prime} 35^{\prime \prime} \mathrm{E}, 126 \mathrm{~m}$ a.s.l., 18.IX.2016, leg. and det. A. Rimac s.n., conf. A. Alegro, ZA(ZA45480, ZA45481, ZA45482)

It was frequent on megalithal substrata ( $>40 \mathrm{~cm}$ in lenght), which formed small cascade, while the abundance was lower downstream, where the substrate was macrolithal $(20-40 \mathrm{~cm}$ in lenght $)$ and water was less turbulent. This locality is not situated in the Mediterranean part of Croatia. The species was associated with several other aquatic moss species such as Cinclidotus riparius, Fontinalis antipyretica, Leptodictyum riparium (Hedw.) Warnst., Rhynchostegium riparioides and a significant amount of cyanobacteria from the Oscillatoriales group, which suggests moderately polluted conditions (Erzberger 2016). Fissidens fontanus is an European Temperate species (Hill \& Preston 1998; Smith 2004) occurring from Mediterranean to Northern Europe (Smith 2004; Frey et al. 2006). It is rare in SE Europe, known only from Bulgaria (Natcheva et al. 2006) and Romania (Stefănut \& Goia 2012), being CR in both countries (Natcheva et al. 2006, Stefannuț \& Goia 2012). The species is known also from neighbouring Italy (Aleffi et al. 2008). Recently, it has been recorded in Greece, on the Lesbos Island (Blockeel \& Nieuwkoop 2016).

\section{Orthotrichum philibertii Venturi}

SPECIMEN EXAMINED. - Croatia. Velebit Nature Park, road connect-

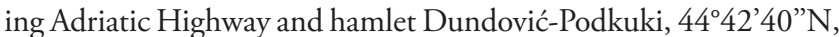
$14^{\circ} 55^{\prime} 19^{\prime \prime}$, 255 m a.s.l., 20.X.2013, leg. V. Šegota s.n., det. B. Papp, conf. T. Kiebacher, BP(BP190917), ZA(ZA45483); Ibidem, hamlet Matović near Šegote village, 4443'34”N, 1454'13”E, $135 \mathrm{~m}$ a.s.l., 20.X.2013, leg. V. Šegota s.n., det. B. Papp, conf. T. Kiebacher, BP(BP190918), ZA(ZA45484).

It was found on the bark of Acer monspessulanum L. on the first site and on the bark of Quercus pubescens Willd. on the second site. Both sites were situated within small thermophilous stands of deciduous woodland dominated by $A$. monspessulanum, Fraxinus ornus L. and Q. pubescens, and are situated in the Mediterranean part of Croatia. The accompanying species were: Frullania dilatata (L.) Dumort., Hypnum cupressiforme, Leptodon smithii (Hedw.) F. Weber \& D. Mohr, Leucodon sciuroides (Hedw.) Schwägr., Porella platyphylla (L.) Pfeiff. and Tortella tortuosa (Hedw.) Limpr. Orthotrichum philibertii is an Oceanic Mediterranean Montane species (Düll 1992; Dierßen 2001), known mostly from Mediterranean parts of Europe (Hodgetts 2015); however it is very rare in the Balkan Peninsula, where it was recorded solely in Greece (Lara et al. 2003), Romania (Stefănut \& Goia 2012) and Serbia (Papp \& Sabovljević 2002). The species is known also from neighbouring Italy (Aleffi et al. 2008). It is CR in Romania (Stefănuț \& Goia 2012) and EN in Serbia (Sabovljević et al. 2004).

\section{Rhabdoweisia crispata (Dicks.) Lindb.}

Specimen examined. - Croatia. Papuk Nature Park, siliceous outcrop above the Šumečica stream near the mountain peak Vranov vrh, 4532'58.3”N, 17³8'38.2”E, 498 m a.s.1., 13.X.2016, leg. and det. A. Alegro \& V. Šegota s.n., conf. B. Papp, BP(BP193752), ZA(ZA45485).

It was found in an acidophilic beech forest, on the bottom of the permanently humid and shaded vertical siliceous outcrop above the stream bank. The species was growing on a tiny layer of loamy soil above the rock, forming loose patches. This locality is not situated in the Mediterranean part of Croatia. Capsules were present, but not abundant. The whole rock was rich in bryophytes, consisting of Blepharostoma trichophyllum (L.) Dumort., Calypogeia fissa (L.) Raddi, Cephalozia bicuspidata (L.) Dumort., Dicranum montanum Hedw., Diplophyllum albicans (L.) Dumort., Grimmia hartmanii Schimp., Heterocladium heteropterum (Brid.) Schimp., Homalia trichomanoides (Hedw.) Brid., Lophocolea heterophylla (Schrad.) Dumort., Pellia epiphylla (L.) Corda, Plagiochila porelloides (Torr. ex Nees) Lindenb., Plagiothecium curvifolium Schlieph. ex Limpr., P. nemorale (Mitt.) A. Jaeger, Polytrichum formosum, Rhizomnium punctatum (Hedw.) T.J. Kop. and Scapania nemorea (L.) Grolle. Rhabdoweisia crispata is a discontinuously Oceanic Boreal-montane species (Hill \& Preston 1998; Smith 2004), present in North-western and Central Europe (Frey et al. 2006). It is extremely rare in SE Europe (Hodgetts 2015), recorded solely in Bulgaria (Natcheva et al. 2006) and Romania (Stefannuț \& Goia 2012). It is known also from neighbouring Italy (Aleffi et al. 2008). The species is VU in Bulgaria (Natcheva et al. 2006).

\section{Schistidium trichodon (Brid.) Poelt var. trichodon}

Specimen EXAmined. - Croatia. Samoborsko gorje Mt, road between Samobor and Slani dol, beneath the hamlet of Gradišće, 45'48'20"N, 15'40'15”'E, $271 \mathrm{~m}$ a.s.l., 14.XI.2016, leg. and det. T. Kiebacher s.n., conf. N. Schnyder, ZA(ZA45486).

It was found on a shaded calcareous rock at the roadside in a forest dominated by Quercus petraea (Matt.) Liebl. and with Vaccinium 
myrtillus L. in the understorey. This locality is not situated in the Mediterranean part of Croatia. Schistidium trichodon is a Boreal Montane species (Düll 1984; Hill \& Preston 1998; Smith 2004), present in Northern, Central and partially Eastern Europe (Smith 2004; Hodgetts 2015). The species is rare, and possibly underrecorded in the Balkans, where it is only known from Montenegro (Dragićević \& Veljić 2006), Romania (Stefănuț \& Goia 2012) and Slovenia (Martinčič 2014). It is known also from neighbouring Italy (Aleffi et al. 2008).

\section{Tortella fasciculata (Culm.) Culm.}

SPeCimen EXAmined. - Croatia. Mt Papuk, Mt Pliš, at Velika village,

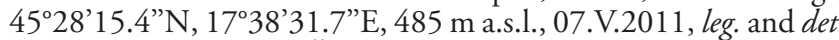
B. Papp, A. Alegro \& V. Šegota s.n., BP(BP182524), ZA(ZA45487, ZA45488); Plitvice Lakes National Park, Čorkova uvala forest

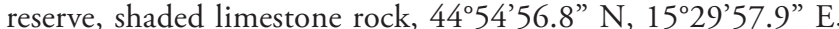
$950 \mathrm{~m}$ a.s.l., 23.VII.2013, leg. and det. B. Papp s.n., BP(BP188161);

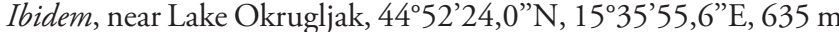
a.s.l., 27.IX.2016, leg. and det. B. Papp, A. Alegro \& V. Šegota s.n., BP(BP191538)

On the Mt Papuk the species was found on limestone rocks along the road, together with Barbula convoluta Hedw., B. unguiculata Hedw. Brachytecium glaerosum (Spruce) Schimp., Bryoerythrophyllum recurvirostrum (Hedw.) P.C. Chen, Campyliadelphus chrysophyllus (Brid.) R.S. Chopra, Campylophyllum calcareum (Crundw. \& Nyholm) Hedenäs, Didymodon acutus (Brid.) K. Saito, D. fallax (Hedw.) R.H. Zander, D. rigidulus Hedw., D. sinuosus (Mitt.) Delonge, D. vinealis (Brid.) R.H. Zander, Tortella squarrosa (Brid.) Limpr., Trichostomum crispulum Bruch and Weisia controversa Hedw.

Both findings within Plitvice Lakes National Park were on shaded limestone rocks; however first one was within Dinaric fir-beech primeval forest in Čorkova uvala, while the second was within thermophilous vegetation near Lake Okrugljak. None of the localities are situated in the Mediterranean part of Croatia. The accompanying species in Čorkova uvala were Alleniella complanata (Hedw.) S. Olsson, Enroth \& D. Quandt, Apometzgeria pubescens (Schrank) Kuwah., Anomodon rostratus (Hedw.) Schimp., Brachythecium salebrosum, Cirriphyllum crassinervium (Taylor) Loeske \& M. Fleisch., Ctenidium molluscum, Dicranum scoparium, Eurhynchium angustirete (Broth.) T.J. Kop., Fissidens dubius, Homomallium incurvatum, Hylocomium splendens, Isopterygiopsis pulchella (Hedw.) Z. Iwats., Mnium stellare Hedw., Rhytidiadelphus loreus (Hedw.) Warnst. and $R$. triquetrus (Hedw.) Warnst.. The accompanying species in Okrugljak were: Barbula crocea, Campyliadelphus chrysophyllus, Ctenidium molluscum, Didymodon ferrugineus (Schimp. ex Besch.) M.O. Hill, Fissidens dubius, Gymnostomum calcareum Nees \& Hornsch., Preissia quadrata (Scop.) Nees. and Pseudoleskeella catenulata (Brid. ex Schrad.) Kindb.

Integrative taxonomical approach using both molecular and morphological data (Köckinger \& Hedenäs 2017), showed that in the last decades the name Tortella bambergeri auct. has been assigned to two independent species: Tortella fasciculata and T. pseudofragilis (Thér.) Köckinger et Hedenäs. Meanwhile, T. bambergeri (Schimp.) Broth. is conspecific with T. tortuosa s.l. Therefore, we reviewed the collections from Croatia identified as T. bambergeri recently recorded (Papp et al. 2013a, b, c). We concluded that specimens from Mt Papuk and Plitvice Lakes belong to T. fasciculata. All these specimens had a central stem strand and the nerve in the upper part of the leaves covered by isodiametric laminal cells. According to Köckinger \& Hedenäs (2017), T. fasciculata is a distinctly thermophilous moss that can be characterised as a Suboceanic-sub-mediterranean floristic element; it has been recognised in Central, Northern and Western Europe so far. While in Central Europe and Sweden it usually occurs on warm and south-facing places, in Western Europe and the mountainous parts of the Mediterranean it comes on generally moister and more shaded habitats; the species inhabits calcareous rocks, but it can also be found on base-rich siliceous rocks, and usually ascends up to $1200 \mathrm{~m}$. This is the first record in SE Europe.

\section{NOTEWORTHY RECORDS}

Didymodon tophaceus subsp. sicculus (M.J. Cano, Ros, García-Zam. \& J. Guerra) Jan Kučera

SPeCimen EXAMINED. - Croatia. Island of Rab, Ciganka Bay at

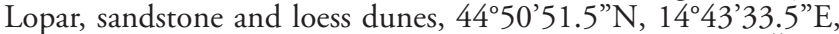
$18 \mathrm{~m}$ a.s.l., 15.VIII.2015, leg. and det. B. Papp, A. Alegro \& V. Šegota s.n., conf. J. Kučera, BP(BP190818).

It was found on bare, sandy soil, along paths going through the Erica arborea L. dominated macchia, situated in the very north-east of the island of Rab, belonging to the Mediterranean part of Croatia and where sandstone and loess are present along the highly indented coastline. These habitats are extremely rare on the dominantly rocky limestone eastern Adriatic coast. The specimen was growing with Barbula unguiculata, Dicranella howei Renauld \& Cardot, Funaria hygrometrica Hedw. and Tortella flavovirens (Bruch) Broth. Didymodon tophaceus subsp. sicculus is a Mediterranean-subcontinental element (Dierßen 2001) known mostly from circum-Mediterranean countries and several outlying populations (Kučera et al. 2018). This is the second known locality of this rare taxon in Croatia, where it was discovered on salty pastures in the easternmost parts of the country (village of Trpinja) (Papp et al. 2016). The taxon was recorded in other several Balkan countries: Greece (Blockeel et al. 2002) Montenegro (Cvetić \& Sabovljević 2004), Slovenia (Blockeel et al. 2009), Bulgaria and Serbia (Papp et al. 2012) and Albania (Marka et al. 2013). It is known also from neighbouring Italy (Aleffi et al. 2003, 2008). Currently, both known Croatian populations are threatened by agriculture and tourism, in the continental and Adriatic parts of the country respectively.

\section{Ephemerum serratum (Hedw.) Hampe}

Specimen eXAmined. - Croatia. Istrian Peninsula, Gornji Ka-

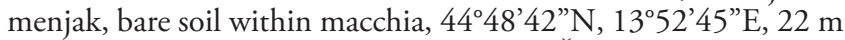
a.s.l., 1.I.2016, leg. and det. N. Vuković, V. Šegota \& A. Alegro s.n., ZA(ZA45491); Island of Molat, Zapuntelsko Polje, shallow depres-

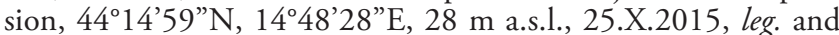
det. A. Alegro, V. Šegota, N. Vuković \& Z. Sedlar s.n. ZA(ZA47327); Ibidem, 8.XII.2015, leg. Z. Sedlar s.n., det. V. Šegota \& A. Alegro, ZA(ZA45490).

At Istrian Peninsula the species occurred on patches of bare soil, on an earthy pathway. The site was located in the zone of Mediterranean macchia vegetation, and the species was found along with other ephemerals: Fossombronia caespitiformis De Not. ex Rabenh. subsp. caespitiformis, Oxymitra incrassata (Brot.) Sérgio \& Sim-Sim, Riccia michelii Raddi, $R$. nigrella DC. and Southbya nigrella (De Not.) Henriq. As a side note, our collected specimens had distinct untoothed leaves, thus resembling Ephemerum stellatum H. Philib. (cf. Frahm \& Frey 2004; Smith 2004; Frey et al. 2006; Infante et al. 2010), which was synonymized with E. serratum (Holyoak 2010). On the island of Molat the species was found along with a rare, ephemeral vascular plant Corrigiola litoralis L. (Vuković et al. 2018), on the bare soil in a seasonally inundated area characterized by damp, shallow depressions and channels. Noteworthily, these habitats are known as "Mediterranean temporary ponds", and are very significant in the context of conservation of rare and endangered vascular plant species (Zacharias et al. 2007). They are facing a rapid decline worldwide (Rhazi et al. 2012) and are therefore listed as a priority habitat in the Habitats Directive (European Commission 2007). Specimens collected had finely papillose spores surrounded by hyaline membrane, thus resembling Ephemerum minutissimum 
Lindb. (Risse 1996, 1997; Smith 2004; Frey et al. 2006). However, more recently, a new perspective on this group was provided by Ellis \& Price (2015) who, as a consequence of nomenclature revision, have placed $E$. minutissimum Lindb. in synonymy with E. serratum. Ephemerum serratum is a Temperate element (Smith 2004) distributed across Europe (Hodgetts 2015). The species was previously reported in Croatia on the island of Rab (Düll 1999) and in Vrhovinsko Polje (Alegro et al. 2014). It is known from many SE European countries, e.g. Bulgaria, Greece, Montenegro, Serbia and Slovenia (Sabovljević et al. 2008) and has recently been discovered in Albania (Marka \& Sabovljević 2011). The species is known also from neighbouring Hungary (Papp et al. 2010b) and Italy (Aleff et al. 2008). It is EN in Romania (Stefănuț \& Goia 2012) and VU in Serbia and Montenegro (Sabovljević et al. 2004).

\section{Mannia triandra (Scop.) Grolle}

Specimen eXAmined. - Croatia. Plitvice Lakes National Park, shaded limestone and dolomite rocks at Lake Gradinsko Jezero,

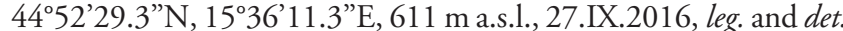
B. Papp, A. Alegro \& V. Šegota s.n., BP(BP 52905/H, BP52915/H), ZA(ZA 45489).

It was found in small, earthy pits and cavities of vertical rocks, growing intermixed with Preissia quadrata. This locality is not situated in the Mediterranean part of Croatia. Some of the bryophyte species growing nearby were Campylophyllum halleri (Hedw.) M. Fleisch., Fissidens taxifolius Hedw., Gymnostomum calcareum, Leiocolea collaris, Lejeunea cavifolia (Ehrh.) Lindb., Pseudoleskeella catenulata, Ptychostomum capillare (Hedw.) Holyoak \& N. Pedersen, Ptychostomum zieri (Hedw.) Holyoak \& N. Pedersen and Rhynchostegium murale (Hedw.) Schimp. This is the second reliable record of the species in Croatia, after its recent discovery on Mt Žumberačka Gora (Alegro et al. 2015). Mannia triandra is a Circumpolar, Subarcticsubalpine element (Düll 1999). It is widely distributed in Central and Southern Europe with its centre of distribution in the Alps (Frey et al. 2006). Historically, it is known from Albania (Baumgartner 1915; Bischler et al. 1980), Bosnia and Herzegovina (Maly 1928), Bulgaria (Ganeva \& Natcheva 2003), Macedonia (Zabijakin 1960), Montenegro (Duda 1965), Romania (Stefănuț \& Goia 2012), Serbia (Sabovljević et al. 2004) and Slovenia (Martinčič 2011), but in Bosnia and Herzegovina, Macedonia and Slovenia there are no recent records (Sabovljević \& Natcheva 2006; Ros et al. 2007). The species is known also from neighbouring Hungary (Németh \& Papp 2011) and Italy (Aleffi et al. 2008). It is CR in Bulgaria (Natcheva et al. 2006) and VU in Romania (Stefănut \& Goia 2012). Moreover, it is listed in the Bern Convention (Council of Europe 1979), and is one of only four Croatian bryophytes listed on the Habitat Directive (European Commission 2007).

\section{Oxystegus tenuirostris (Hook. \& Taylor) A.J.E. Sm.}

SpeCimen EXAmined. - Croatia. Samoborsko gorje Hills, near the road between Samobor and Slani dol, beneath the hamlet of Gradišće, 4548'18”N, 15³9'59”E, 300 m a.s.l., 14.XI.2016, leg. T. Kiebacher, V. Šegota \& A. Alegro s.n., det. T. Kiebacher 1295., conf. A. Bergamini, private collection T. Kiebacher.

It was found on rock outcrops on a steep slope within an acidophilus beech forest, in a locality not situated in the Mediterranean part of Croatia. The siliceous geological bedrock facilitates the occurrence of species such as Bazzania tricrenata (Wahlenb.) Lindb., B. trilobata (L.) Gray, Dicranella heteromalla, Hedwigia ciliata, Sphagnum quinquefarium (Braithw.) Warnst. and Trichocolea tomentella (Ehrh.) Dumort.. Oystegus tenuirostris is a Circumpolar Boreo-temperate species (Hill \& Preston 1998; Smith 2004), scattered in montane regions throughout Europe (Frey et al. 2006). The species was recorded for the first time in Croatia, in Golubinjak Forest in Gorski Kotar Region (Papp et al. 2013a). In SE Europe it is also known from Albania (Papp et al. 2010a), Bulgaria (Natcheva et al. 2006), Greece (Düll 1995), Montenegro (Dragićević \& Veljić 2006), Romania (Stefănut \& Goia 2012), Serbia (Sabovljević \& Stevanović 1999) and Slovenia (Martinčič 2003). It is known also from neighbouring Hungary (Papp et al. 2010b) and Italy (Aleffi et al. 2008).

\section{Sphaerocarpos michelii Bellardi}

Specimen EXAmined. - Croatia. Town of Slatina, settlement Donji Meljani, Sladojevački lug, on arable fields, 45 44'6.71”N, 17'37’35.9”E, 112 m. a.s.l., 19.III.2015, leg. and det. D. Prlić s.n., ZA(ZA47330); Ibidem, 4544'6.15”N, 17³7'16.87”'E, $114 \mathrm{~m}$ a.s.l., 19.III.2015, leg. and det. D. Prlić s.n., ZA(ZA47483), Ibi-

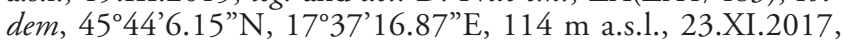
ZA(ZA47484); Ibidem, Radlovac, along vineyard, 4543'53.96”N, 17³6' 56.97”'E, $156 \mathrm{~m}$ a.s.l., 5.III.2015, leg. and det. D. Prlić s.n., ZA(ZA47331); Ibidem, settlement Bakić, Vrela, on arable field, 45 45'32.66” N, 1742'4.92”E, $106 \mathrm{~m}$ a.s.l., X.2015, leg. and det. D. Prlićs.n., ZA(ZA47332).

In Sladojevački lug the specimens were recorded in high abundance on loamy soil of corn and soya bean stubble fields, with Entosthodon fascicularis (Hedw.) Müll. Hal., Marchantia polymorpha subsp. ruderalis Bischl. \& Boisselier, Riccia glauca L., R. sorocarpa Bisch. and Tortula truncata (Hedw.) Mitt.. In Radlovac the species was less abundant, growing along an old vineyard in the northerly exposed hilly area with Barbula convoluta, B. unguiculata, Marchantia polymorpha subsp. ruderalis, Ptychostomum capillare and Tortula truncata. In Vrela, the species was scattered on loamy and sandy soil of the tobacco stubble field with Riccia sorocarpa and R. glauca. None of the new localities are situated in the Mediterranean part of Croatia. The species was recorded only in 1923 and 1924 on the bottom of the dried Maksimir Lake in Zagreb (Horvat 1932). It is a Mediterranean-Atlantic-Macaronesian species (Hill \& Preston 1998; Frey et al. 2006), present in Southern and partially Central Europe (Frey et al. 2006; Hodgetts 2015). It is very rare across the Balkan Peninsula, found only in Bulgaria (Natcheva et al. 2006) and Greece (Düll 1995). The species is known also from neighbouring Italy (Aleffi et al. 2008).

\section{Acknowledgements}

The research was supported by the public institutions Papuk Nature Park and Plitvice Lakes National Park, by the Croatian State Institution for Water Management "Hrvatske vode" and the city of Zadar. The authors wish to thank the editor and the referees for their valuable remarks.

\section{REFERENCES}

Aleffi M., Sabovljević M. \& Tacchi R. 2003. - Didymodon sicculus M.J. Cano, Ros, García-Zamora \& J. Guerra (Pottiaceae, Musci), new to Italy. Cryptogamie, Bryologie 24: 49-51.

Aleffi M., Tacchi R. \& Cortini Pedrotti C. (eds) 2008. Check-list of the Hornworts, Liverworts and Mosses of Italy. Bocconea 22: 6-255.

Alegro A., ŠEGOTA V. \& PAPP B. 2012. - Bryological research of Croatia - a historical overview. Studia botanica Hungarica 43: 5-12. Alegro A., PApp B., Szurdoki E., ŠEgOtA V., ŠApić I. \& VuKelić J. 2014. - Contribution to the bryophytes flora of Croatia III. Plitvička jezera National Park and adjacent areas. Studia 
Botanica Hungarica 45: 49-65. https://doi.org/10.17110/StudBot.2014.45.49

Alegro A., Śegota V. \& PApp B. 2015. - A contribution to the bryophyte flora of Croatia IV: Žumberačka gora Mts. Studia botanica Hungarica 46 (1): 5-24. https://doi.org/10.17110/ StudBot.2015.46.1.5

BAUMGARTNER J. 1915. — Verzeichnis der von I. Dörfler auf seiner Reise im albanisch-montenegrinischen Grenzgebiete im Jahre 1914 gesammelten Moose. Osterreichische Botanische Zeitschrift 65 (10-12): 312-319.

Bischler H., JoveT-Ast S. \& BAUdoin R. 1980. — Hépatiques de la côte albanaise. Cryptogamie, Bryologie, lichénologie 1: 247-267.

Blockeel T. L., Ros R. M., Sabovlević M., Cano M. J., Gallego M. T. \& MuÑOz J. 2002. - New and interesting bryophyte records for Greece. Cryptogamie, Bryologie 23: 149-155.

Blockeel T. L., BaKalin V. A., BednareK-Ochyra H., Ochyra R., Buck W. R., ChOI S., CYKowsKa B., ERdAĞ A., ERZBERGER P., Kirmaci M., KÜRSCHNER H., Lebouvier M., SABOVlJeVIĆ M., Sabovljević A., Schröder W., Singh S. M., Sun B.-Y., Townsend C. C., VÁ J., Yanitas Ö. T. 2009. - New national and regional bryophyte records, 20. Journal of Bryology 31: 54-62. https://doi.org/10.1179/jbr.2009.31.1.64

Blockeel T. L. \& NieuwKOOP J. A. W. 2016. - The Bryophyte Flora of Lesbos. Herzogia 29 (1): 1-34. https://doi.org/10.13158/ heia.29.1.2016.1

Brugués M. \& Ruiz E. 2015. - Dichodontium Schimp. In: Brugués M. \& Guerra J. (eds), Flora Briofitica Ibérica volumen II. Archidiales, Dicranales, Fissidentales, Seligeriales, Grimmiales. Murcia, Universidad de Murcia, Sociedad Espańola de Briología: 56-60.

CONSERVATION INTERNATIONAL BIODIVERSITY HOTSPOTS 2018. CEPF Mediterranean Basin. https://www.cepf.net/our-work/ biodiversity-hotspots/mediterranean-basin. Accessed on 10 February 2018.

Council Of Europe 1979. - The Convention on the Conservation of European Wildlife and Natural Habitats. Bern. http:// conventions.coe.int/Treaty/EN/Treaties/Html/104.htm. Accessed on 10 February 2018.

Cvetić T. \& SABOVlJEVIĆ M. 2004. - New and interesting bryophyte records for Montenegro. Phytologia Balcanica 10 (2-3): 171-173. https://doi.org/10.13158/heia.31.1.2018.436

DiERBEN K. 2001. - Distribution, ecological amplitude and phytosociological characterization of European bryophytes. Bryophytorum Bibliotheca 56: 1-289.

DragićeVIĆ S. \& Veljić M. 2006. — Pregled mahovina Crne Gore. Podgorica, Prirodnjački muzej Crne Gore. 1-99.

DUDA J. 1965. - Beitrag zur Erforschung der Lebermoose Jugoslawiens. Acta Botanica Croatica 24: 79-82.

DÜLL R. 1984. - Distribution of the European and Macaronesian mosses (Bryophytina) II. Bryologische Beiträge 4: 1-114.

DÜLl R. 1992. - Distribution of the European and Macaronesian mosses (Bryophytina). Annotations and Progress. Bryologische Beiträge 8/9: 1-223.

DÜlL R. 1995. - Bryophytes of Greece. Bryologische Beiträge 10: $1-229$.

DÜLL R. 1999. - Bryological results of some excursions in former Yugoslavia. Bryologische Beiträge 11: 95-110.

Ellis L. T., Alegro A, Bednarek-Ochyra H., Ochyra R., Bergamini A., Cogoni A., Erzberger P., Górski P., Gremmen N., Hespanhol H., Vieira C., Kurbatova L. E., Lebouvier M., Martinčič A., Asthana A. K., Gupta R., Nath V, NatcheVA R., Ganeva A., ÖZdemir T., Batan N, Plášek V., Porley R. D., Randić M., SaWicki J., Schroder W., Sérgio C., SMith V. R., Sollman P. S., Ştefănut., Stevenson C. R., SuÁrez G. M., Surina B., Uyar G. \& Modrić Surina Ž. 2012a. New national and regional bryophyte records, 31. Journal of Bryology 34 (2): 123-134. https://doi.org/10.1179/17432820 12Y.0000000009

Ellis L. T., Alegro A., Bansal P., Nath V., CyKowska B., BednareK-
Ochyra H., Ochyra R., DULin M.V. ERZBerger P., Garcia C., Sérgio C., Claro D., Stow S., Hedderson T. A., Hodgetts N. G., Hugonnot V., KuČera J., Lara F., Pertierra L., Lebouvier M., Liepina L., MeŽAKa A., Strazdina L., MadŽUle L., Rériha I., Mazooji A., Natcheva R., Phephu N., Philippov D. A., Plášek V., Činal L., Pócs T., Porley R. D., Sabovljević M., Salimpour F., Behroozmand Motlagh M., Sharifnia F., AKHOONDi DARZIKOlaEI S., SCHÄFER-VERWIMP A., ŠEGOTA V., Shaw A.J., Sim-Sim M., Sollman P., Spitale D., Hölzer A., Stebel A., VÁŇA J., VAN RoOy J. \& VonČIna G. 2012b. New national and regional bryophyte records, 32. Journal of Bryology 34 (3): 231-246. https://doi.org/10.1179/17432820 12Y.0000000019

Ellis L. T., Aleffi M., Tacchi R., Alegro A., Alonso M., Asthana A. K., Sahu V., Biasuso A. B., Callaghan D. A., Ezer T., Kara R., Seyli T., Garilleti R., Gil-López M.J., GWynne-Evans D., Hedderson T. A., Kiebacher T., Larraín J., Long D., Luth M., Malcolm B., Mamontov Y. S., Newsham K. K., Nobis M., Nowak A., Ochyra R., PaWlikowski P., PlášeK V., Činal L., Potemkin A. D., Puche F., Rios D., Gallego M. T., Guerra J., SaWicki J., SCHÄFEr-VerWimp A., SegarraMoragues J. G., ŠEgota V., Sofronova E. V., Ştefănuț S., SzŰcs P., Bidló A., Papp B., SZurdoki E., Tan B. C., VÁŇ́ J., Vigalondo B., Draper I., Lara F., Yoon Y.-J., Sun B.-Y. \& Nishimura N. 2014. - New national and regional bryophyte records, 41. Journal of Bryology 36 (4): 306-324. https://doi.org /10.1179/1743282014Y.0000000123

Ellis L. T., Alegro A., Šegota V., Bakalin V. A., Barone R., Borovichev E. A., Hugonnot V., Lebouvier M., Nobis M., NowaK A., Ochyra R., Papp B., SZURdoki E., PiwowarczyK R., Plášek V., Čihal L., Ren Z.-J., Sabovljević M., Sérgio C., Garcia C. A., Melo I., SaWicki J., Stebel A., Ştefănut S., IOn R., Manole A., TZiortzis I., Xiong Y. \& ZHaO Z.-T. 2015. - New national and regional bryophyte records, 44 Journal of Bryology 37 (3): 228-241. https://doi.org/10.1179/1 743282015 Y.0000000014

Ellis L. T. \& Price M. J. 2015. - Review of the type specimens of species described by J. Hedwig in Phascum Hedw. (Pottiaceae). Journal of Bryology 37 (1): 23-41. https://doi.org/10.1179/174 3282014Y.0000000116

Ellis L. T., Aleffi M., Alegro A., Šegota V., Asthana A. K., Gupta R., Singh V. J., Bakalin V. A., Bednarek-Ochyra H., Cykowska-Marzencka B., Benitez A., Borovichev E. A., Vilnet A. A., Konstantinova N. A., Buck W. R., CaCciatoro C., Sérgio C., Csiky J., Deme J., Kovács D., DamSholt K., Enroth J., Erzberger P., Fedosov V. E., Fuertes E., Gradstein S. R., Gremmen N. J. M., HallingbäcbryoK T., Jukonienė I., Kiebacher T., Larraín J., Lebouvier M., Lüth M., Mamontov Yu S., Potemkin A. D., Nemeth C. S., NieuWKoOp J. A. W., Nobis M., Węgrzyn M., WietrzyK P., Osorio F., Parnikoza I., Virchenko V. M., Peralta D. F., Carmo D. M., Plášek V., SKoupá Z., Poponessi S., Venanzoni R., Puche F., Purger D., Reeb C., Rios R., Rodriguez-Quiel E., Arrocha C., Sabovljević M., Nikolić N., Sabovljević A. D., Dos Santos E. L., Segarra-Moragues J. G., ŞTEFĂNUȚ S. \& STONČIUS D. 2016. - New national and regional bryophyte records, 48. Journal of Bryology 38 (3): 235-259. https:// doi.org/10.1080/03736687.2016.1206685

Ellis L. T., Alataș M., Alegro A., Šegota V., Ozimec S., Vuković N., Koletić N., Prlić D., Bontek M., Asthana A. K., Gupta R., Sahu V., Rawat K. K., BaKalin V. A., Klimova K. G., Baráth K., Beldiman L. N., Csiky J., Deme J., Kovács D., Cano M. J., Guerra J., Czernyadjeva I. V., Dulin M. V., Erzberger P., Ezer T., Fedosov V. E., Fontinha S., Sim-Sim M., Garcia C. A., Martins A., Granzow-De La Cerda I., Sáez L., Hassel K., Weibull H., Hodgetts N. G., Infante M., Heras P., Kiebacher T., KuČera J., Lebouvier M., Ochyra R., Ören M., Papp B., Park S. J., Sun B.-Y., PlášEK V., Poponessi S., 
Venanzoni R., Purger D., Reis F., Singila M., Stebel A., ŞTEFĂNUȚ S., Uyar G., VonČInA G., Wigginton M. J., YONG K.-T., CHAn M. S. \& YoON Y.-J. 2017. - New national and regional bryophyte records, 52. Journal of Bryology 39 (3): 285304. https://doi.org/10.1080/03736687.2017.1341752

ERZBERGER P. \& PAPP B. 2004. — Annotated checklist of Hungarian bryophytes. Studia botanica Hungarica 35: 91-150.

ERZBERGER P. \& PAPP B. 2007. — New and noteworthy bryophyte records from Montenegro and Serbia. Willdenowia 31 (1):339-351.

ERZBERGER P. 2016. - The genus Fissidens (Fissident aceae, Bryophyta) in Hungary. - Studia Botanica Hungarica 47 (1): 41-139. https://doi.org/10.17110/StudBot.2016.47.1.41

European COMMISSION 2007. — Council Directive 92/43/EEC of 21 May 1992 on the conservation of natural habitats and of wild fauna and flora - consolidated version 01/01/2007. http:// eur-lex.europa.eu/LexUriServ/LexUriServ.do?uri=CONSLEG:1 992L0043:20070101:EN:PDF. Accessed on 10 February 2018.

EurO+Med 2018. - Euro+Med PlantBase - the information resource for Euro-Mediterranean plant diversity. http://www. emplantbase.org/home.html. Accessed on 10 February 2018.

Frahm J.-P. \& FrEY W. 2004. - Moosflora. vol. 4. Auflage. Stuttgart, Verlag Eugen Ulmer. 1-538.

FreY W., FrahM J.-P., Fischer, E. \& Lobin W. 2006. - The Liverworts, Mosses and Ferns of Europe. Colchester, Harley Books.

GAMISANS J. \& HÉBRARD J.-P. 1980. - À propos de la végétation des forêts en Grèce du nord est (Macédonie orientale et Thrace occidentale). Documents phytosociologiques 5: 243-289.

GANEVA A. \& NATCHEVA R. 2003. - Check-list of the bryophytes of Bulgaria with data on their distribution. I. Hepaticae and Anthocerotae. Cryptogamie, Bryologie 26 (2): 209-232.

GŁOWACKI J. 1906. - Bryologische Beiträge aus dem Okkupationsgebiete. I. Verhandlungen der Zoologisch-Botanischen Gesellschaft in Wien 56: 186-207.

GŁoWACKI J. 1912. - Moosflora der Steiner Alpen. Carinthia II 102: 13-47, 130-146.

Hill M. O. \& Preston C. D. 1998. - The geographical relationships of British and Irish bryophytes. Journal of Bryology 20: 127-226.

HodgetTs N. G. 2015. - Checklist and Country Status of European bryophytes - towards a new Red List for Europe. Irish Willife Manuals No. 84. National Parks and Wildlife Services, Department of Arts, Heritage and the Gaeltacht. 1-125.

HOLYOAK D. T. 2010. — Notes on taxonomy of some European species of Ephemerum (Bryopsida: Pottiaceae). Journal of Bryology 32: 122-132. https://doi.org/10.1179/037366810X12578498136192

HorvaT I. 1932. — Građa za briogeografiju Hrvatske. Acta Botanica Croatica 7: 73-128.

Infante M., SÉRgIO C. \& Heras P. 2010. - Ephemerum Hampe. In: Guerra J., Brugués M., Cano M. J. \& Cros R. M. (eds), Flora Brofitica Ibérica volumen IV. Funariales, Splachnales, Schistotegales, Bryales, Timmiales. Murcia, Universidad de Murcia, Sociedad Espańola de Briología: 16-25.

IuCN Standards And PetiTions Subcommittee 2017. — Guidelines for Using the IUCN Red List Categories and Criteria. Ver. 13. Prepared by the Standards and Petitions Subcommittee. http://www.iucnredlist.org/documents/RedListGuidelines.pdf. Accessed on 10 February 2018.

KÖCKINGER H. \& HEDENÄS L. 2017. - A farewell to Tortella bambergeri (Pottiaceae) as understood over the last decades. Journal of Bryology 39 (3): 213-225. https://doi.org/10.1080/0373668 7.2017.1307313

Kučera J., Blockeel T. L., Erzberger P., Papp B., Soldán Z., Vellak K., Werner O. \& Ros R. M. 2018. — The Didymodon tophaceus complex (Pottiaceae, Bryophyta) revisited: new data support the subspecific rank of currently recognized species. Cryptogamie, Bryologie 39 (2): 241-257. https://doi.org/10.7872/ cryb/v39.iss2.2018.241

Lara F., BlockeEl T. L., Garilleti R. \& Mazimpaka V. 2003. Some interesting Orthotrichum species from mainland Greece and Evvia. Journal of Bryology 25: 129-134. https://doi. org/10.1179/037366803235001805

MaLY K. 1928. — Prilozi za Floru Bosne i Hercegovine. Glasnik Zemaljskog muzeja u Bosni i Hercegovini 40 (1): 107-166.

Marka J. \& SABOVlJeVić M. 2011. - New bryophyte records from Albania. Journal of Bryology 33 (1): 74-76. https://doi.org /10.1179/037366810X12814343698179

Marka J., Erzberger P. \& PAPp B. 2013. - New and interesting moss records from Albania. Journal of Bryology 35 (2): 152-155. https://doi.org/10.1179/1743282013Y.0000000053

MARTINČIČ A. 2003. — Seznam lisnatih mahov (Bryopsida) Slovenije. Hacquetia 2 (1): 91-166.

MARTINČIČ A. 2011. - Annotated Checklist of Slovenian Liverworts (Marchantiophyta) and Hornworts (Anthocerotophyta) Scopolia 72: 1-38

MARTINČIČ A. 2014. - Mahovna flora fitogeografskog podobmočja Karavanke (Slovenija). Haquetia 13 (2): 307-353.

Natcheva R., Ganeva A. \& SpIRIDOnOv G. 2006. — Red list of the bryophytes in Bulgaria. Phytologia Balcanica 12 (1): 55-62.

Németh C. S. \& Papp B. 2011. - Mannia triandra (Scop.) Grolle in the Transdanubian Mountain Ranges (Hungary). Studia Botanica Hungarica 42: 23-29.

PAPP B. \& SABOVLJEVIĆ M. 2002. - The bryopyhte flora of Tara National Park (W Serbia, Yugoslavia). Studia Botanica Hungarica 33: 25-39.

PAPp B. \& ERZBERger P. 2005. - The bryophyte flora of GolijaStudenica Biosphere Reserve and some adjacent sites (SW Serbia, Serbia-Montenegro). Studia Botanica Hungarica 36: 101-116.

PAPp B. \& ERZBERGER P. 2007. — Contributions to the bryophyte flora of Western Stara Planina Mts (E Serbia). Studia Botanica Hungarica 38: 95-123.

PAPP B. \& SABOVLJEVIĆ M. 2009. — Notes on some new and interesting bryophyte records from Croatia. Journal of Bryology 31: 272-275. https://doi.org/10.1179/037366809X12469790518448

Papp B., Erzberger P. \& Marka J. 2010a. - Contribution to the bryophyte flora of Eastern Albania (Korça and Kolonja Districts). Studia Botanica Hungarica 41: 61-88.

Papp B., Erzberger P., Ódor P., Hock Z. S., SzÖvényi P., SZurDOKI E. \& TÓTH Z. 2010b. - Updated checklist and Red list of Hungarian bryophytes. Studia Botanica Hungarica 41: 31-59.

PAPP B. \& ERZBERGER P. 2011. — Additions to the bryophyte flora of the Tara river canyon and Durmitor area, Montenegro. Studia botanica Hungarica 42: 31-39.

Papp B., Natcheva R. \& Sabovljević M. 2012. — Didymodon sicculus, new to Bulgaria, Serbia and some notes on its ecology. Nova Hedwigia 95 (1-2): 221-226. https://doi.org/10.1127/00295035/2012/0039

Papp B., Alegro A., Šegota V., Šapić I. \& Vukelić J. 2013a. Additions to the bryophyte flora of Croatia. Journal of Bryology 35 (2): 140-143. https://doi.org/10.1179/1743282013Y.0000000046 Papp B., Alegro A., Š́egota V., Šapić I. \& Vukelić J. 2013b. Contribution to the bryophyte flora of Croatia II. The Northern Velebit. Studia Botanica Hungarica 44: 213-228.

Papp B., Alegro A., Šegota V., Šapić I. \& Vukelić J. 2013c. Contribution to the bryophyte flora of Croatia I. Gorski kotar Region (W Croatia). Studia Botanica Hungarica 44: 193-211.

Papp B., Alegro A., Erzberger P., Szurdoki E., Šegota V. \& SABOVLJEVIĆ M. 2016. - Bryophytes of saline areas in the Pannonian region of Serbia and Croatia. Studia Botanica Hungarica 47 (1): 141-150. https://doi.org/10.17110/StudBot.2016.47.1.141

PaVletić Z. 1955. - Prodromus flore briofita Jugoslavije. Zagreb, Jugoslavenska akademija znanosti i umjetnosti. 1-578.

Rhazi L., Grillas P., SABER E.-R., Rhazi M., Brendonck L. \& WATERKEYN A. 2012. — Vegetation of Mediterranean temporary ponds: a fading jewel? Hydrobiologia 689: 23-36. https:// doi.org/10.1007/s10750-011-0679-3

RISSE S. 1996. - Ephemerum minutissimum Lindb. and E. serratum (Hedw.) Hampe. The Bryological Times 90: 6. 
RisSE S. 1997. — Errata. The Bryological Times 92: 7.

Ros R. M., Mazimpaka V., Abou-Salama U., Aleffi M., Blockeel T. L., Brugués M., Cano M. J., Cros R. M., Dia M. G., Dirkse G. M., El Saadawi W., Erdă̆ A., Ganeva A., GonzálezMancebo J. M., Herrnstadt I., Khalil K., KÜrschner H., LANFRANCO E., LOSADA-LiMA A., REFAI M. S., RODRÍGEZ-NuÑEZ S., Sabovljević M., Sérgio C., Shabbara H., Sim-Sim M. \& SÖDERSTRÖM L. 2007. - Hepatics and Anthocerotes of the Mediterranean, an annotated checklist. Crytogamie, Bryologie 28 (4): 351-437.

Ros R. M., Mazimpaka V., Abou-Salama U., Aleffi M., Blockeel T. L., Brugués M., Cros R. M., Dia M. G., Dirkse G. M., Draper I., El-SaAdaWI W., ERdaĞ A., GaneVa A., Gabriel R., González-Mancebo J. M., Granger C., Herrnstadt I., Hugonnot V., Khalil K., KÜRSChNer H., Losada-Lima A., Luís L., Mifsud S., Privitera M., Puglisi M., Sabovljević M., Sérgio C., Shabbara H., Sim-Sim M., SotiauX A., TaCchi R., Vanderpoorten A. \& Werner O. 2013. - Mosses of the Mediterranean, an annotated checklist. Cryptogamie, Bryologie 34: 99-283. https://doi.org/10.7872/cryb.v34.iss2.2013.99

SAbOVljeVić M. \& STEVANOVIĆ V. 1999. - Moss conspectus of Federal Republic of Yugoslavia. Flora Mediterranea 9: 65-95.

SABOVLJEVIĆ M. 2003. - The hepatic checklist of Croatia. Archives of Biological Sciences 55 (1-2): 59-66. https://doi.org/10.2298/ ABS0302059S

SABOVLJEVIĆ M. 2004. - Comparison of the bryophyte flora of the three southern European mainlands: the Iberian, the Apennine and the Balkan Peninsulas. Braun-Blanquetia 34: 21-28.

Sabovljević M., Cvetić T. \& Stevanović V. 2004. - Bryophyte Red list of Serbia and Montenegro. Biodiversity and Conservation 13: 1781-1790. https://doi.org/10.1023/ B:BIOC.0000029338.97776.66

SABOVLJEVIĆ M. 2006. - Checklist of mosses of Croatia, Archives of biological sciences 58 (1): 45-53.

SABOVLJEVIĆ M. \& NATCHEVA R. 2006. - A check-list of the liverworts and hornworts of southeast Europe. Phytologia Balcanica 12: $169-180$.

Sabovljević M., Natcheva R., Dihoru G., Tsakiri E., Dragićević D., ERDAĞ A. \& PAPP B. 2008. - Check-list of the mosses of SE Europe. Phytologia Balcanica 14 (2): 207-244.

SABOVljeVIĆ M., Alegro A., SABOVljeVIĆ A., Marka J. \& Vujičić M. 2011. - An insight into diversity of the Balkan Peninsula bryophyte flora in the European background. Revue d'Écologie (Terre et Vie) 66: 399-413.

SMith A. J. E. 2004. - The Moss Flora of Britain and Ireland. 2nd edition Cambridge, Cambridge University Press. 1-1012.

STEFĂNUT S. \& GOIA I. 2012. — Checklist and Red List of Bryophytes of Romania. Nova Hedwigia 95 (1-2): 59-104. https:// doi.org/10.1127/0029-5035/2012/0044

Vuković N., Šegota V., Alegro A. \& Sedlar Z. 2018. — Rare plants of threatened habitats - the Croatian case of Corrigiola litoralis L. (Caryophyllaceae). Acta Botanica Croatica. https:// doi.org/10.1515/botcro-2017-0021

WERNER J. 2002. - A comparison of Dichodontium flavescens (Dicks.) Lindb. and D. pellucidum (Hedw.) Lindb. (Bryopsida). Journal of Bryology 24: 215-221. https://doi.org/10.1179/037366802125001385

ZABIJAKIN V. 1960. — Prilog kon poznavanjeto na Hepaticae od planinata Pelister vo Makedonija. Fragmenta Balcanica 3: 85-90.

ZaCharias I., Dimitriou E., DeKKER A. \& Dorsman E. 2007. Overview of temporary ponds in the Mediterranean region: Threats, management and conservation issues. Journal of Environmental Biology 20, 1-2. 